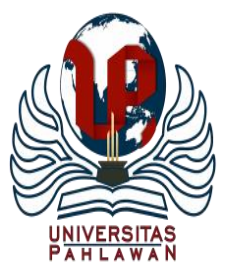

Edukatif : Jurnal Ilmu Pendidikan Volume 3 Nomor 3 Tahun 2021 Halm 919 - 927

EDUKATIF: JURNAL ILMU PENDIDIKAN

Research \& Learning in Education

https:/ledukatif.org/index.php/edukatif/index

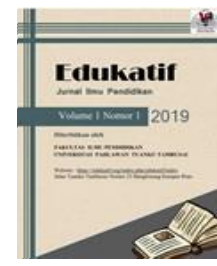

\title{
Peningkatan Sikap Kedisiplinan dan Kemampuan Berpikir Kritis Siswa dengan Penerapan Model Pembelajaran Problem Based Learning
}

\author{
Halimah Dwi Cahyani ${ }^{1 凶}$, Agnes Herlina Dwi Hadiyanti², Albertus Saptoro $^{3}$
}

Universitas Sanata Dharma, Indonesia ${ }^{1,2}$, SD Kanisius Kintelan, Indonesia ${ }^{3}$

E-mail: $\underline{\text { halimahdc@gmail.com}}^{1}$, $\underline{\text { agnes.hadiyanti@gmail.com }}^{2}, \underline{\text { saptoro67@gmail.com }}^{3}$

\begin{abstract}
Abstrak
Penelitian tindakan kelas ini berlatar belakang rendahnya sikap kedisiplinan dan kemampuan berpikir kritis siswa dalam pembelajaran. Tujuan penelitian untuk meningkatkan sikap kedisiplinan dan kemampuan berpikir kritis siswa dengan menggunakan model pembelajaran Problem Based Learning. Materi yang digunakan pada penelitian ini adalah bangun ruang volume kubus dan balok. Penelitian tindakan kelas ini dilaksanakan sesuai dengan model dari Kemmis \& Mc. Targgart. Proses penelitian dilaksanakan dalam dua siklus, setiap siklus ada dua kali pembelajaran. Tahap setiap siklus yaitu perencanaan, pelaksanaan, pengamatan, dan refleksi. Penilaian kedisiplinan dilaksanakan melalui kegaiatan wawancara dengan guru kelas dan observasi, sedangkan penilaian kemampuan berpikir kritis dengan soal tes berupa empat soal uraian diakhir pembelajaran setiap siklus. Objek penelitian adalah siswa kelas VD SD 1 Bantul tahun pelajaran 2020/2021. Hasil penelitian yaitu (1) penggunan model PBL meningkatkan kedisiplinan siswa, (2) penggunaan model PBL meningkatkan kemampuan berpikir kritis siswa. Dari hasil tersebut dapat ditarik kesimpulan bahwa kedisiplinan dan kemampuan berpikir kritis dapat ditingkatkan dengan penerapan model pembelajaran PBL.

Kata Kunci: kedisiplinan, kemampuan berpikir kritis, problem based learning.
\end{abstract}

\begin{abstract}
The background of this classroom action research is due to low discipline and critical thinking of the student during the class. The objective of the study is for increasing the discipline and the critical thinking skills of the student using Problem Based Learning leaning model. The material used in this study is the volume space of cubes and blocks. This classroom action research was carried out in accordance with the model from Kemmis $\&$ Mc. Targgart. The research process was carried out in two cycles, each cycle there were two lessons., namely planning, implementing, observing, and reflecting. Discipline assessment is held through interviews and observations with class teachers, while the assessment of critical thinking skills uses test questions, four essay questions at the end of each learning cycle. The object of the research was students of class VD SD 1 Bantul in the second semester. The results of the study were (1) the use of the PBL could improve students 'discipline, (2) the use of the PBL could improve students' critical thinking skills. From these results it can be concluded that the discipline and critical thinking skills can be improved by the application of the PBL.
\end{abstract}

Keywords: discipline, critical thinking, problem based learning.

Copyright (c) 2021 Halimah Dwi Cahyani, Agnes Herlina Dwi Hadiyanti, Albertus Saptoro

$\triangle$ Corresponding author

Email : halimahdc@gmail.com

DOI : https://doi.org/10.31004/edukatif.v3i3.472

ISSN 2656-8063 (Media Cetak)

ISSN 2656-8071 (Media Online)

Edukatif : Jurnal Ilmu Pendidikan Vol 3 No 3 Tahun 2021 p-ISSN 2656-8063 e-ISSN 2656-8071 
920 Peningkatan Sikap Kedisiplinan dan Kemampuan Berpikir Kritis Siswa dengan Penerapan Model Pembelajaran Problem Based Learning - Halimah Dwi Cahyani, Agnes Herlina Dwi Hadiyanti, Albertus Saptoro

DOI: https://doi.org/10.31004/edukatif.v3i3.472

\section{PENDAHULUAN}

Pendidikan adalah suatu modal utama bagi kemajuan bangsa. Suatu permasalahan yang kerap dihadapi adalah rendahnya mutu pendidikan. Pengembangan berbagai aspek dalam pendidikan adalah salah satu hal penting. Melalui pendidikan, seseorang akan dapat dibentuk secara terus menerus baik secara aspek kognitif maupun afektif khususnya karakter. Pendidikan menurut Undang-Undang Republik Indonesia nomor 20 Tahun 2003 adalah usaha dasar dan terencana untuk mewujudkan suasana belajar dan proses pembelajaran agar siswa secara aktif dapat mengembangkan potensi yang ada pada dirinya untuk memiliki kekuatan spriritual keagamaan, pengendalian diri, kepribadian, akhlak mulia, serta keterampilan yang diperlukan diri, masyarakat, bangsa dan negara (Sisdiknas, 2003: 3). Salah satu karakter yang dapat dibentuk di masa seperti ini adalah kedisiplinan belajar. Kedisiplinan adalah suatu upaya membuat seseorang berada pada sikap serta perilaku yang ditetapkan. Kurangnya kedisplinan pada siswa berakibat pada rendahnya kemampuan berpikir kritis siswa. Berpikir kritis adalah kemampuan berpikir secara logis, reflektif, dan produktif yang diaplikasikan dalam menilai situasi untuk membuat pertimbangnya dan keputusan yang baik (Desmita, 2009: 153). Siswa dapat mengembangkan karakter kedisiplinan untuk mencapai kemampuan berpikir kritis yang baik. Melalui berpikir kritis, hendaknya siswa peka terhadap berbagai hal yang terjadi di lingkungan, kemudian menganalisis dan memahami menggunakan tahapan kerja ilmiah, sehingga berpikir, berperasaan, dan bertindak secara terkendali sesuai dengan kapasitas potensi dalam perilaku yang sehat, berkualitas, dan terjaga integritasnya (Tawil \& Liliasari, 2014: 2).

Kedisiplinan dan kemampuan berpikir kritis adalah suatu hal yang penting dalam kegiatan pembelajaran di kelas. Di beberapa sekolah secara umum kedisiplinan siswa dalam pembelajaran masih relatif kurang, hal itu terlihat dari kebiasaan mengumpulkan tugas yang tidak tepat waktu. Begitu pula dengan perkembangan kemampuan berplikir kritis siswa, banyak dari mereka yang masih menjawab soal dengan kurang mendalam. Hal tersebut sejalan dengan hasil wawancara dengan salah satu guru di SD 1 Bantul, sebagian besar siswa masih mengalami permasalahan dalam hal kedisiplinan dan berpikir kritis dalam pembelajaran matematika. Kendala disiplin yang masih dihadapi di kelas diantaranya tidak mengumpulkan tugas tepat waktu, tidak mengikuti arahan guru pada kegiatan pembelajaran, dan dalam penyelesaian permasalahan matematika belum menggunakan sesuai dengan langkah yang ditentukan.

Berdasarkan uraian di atas, maka diperlukan adanya suatu metode pembelajaran yang dapat mendorong siswa untuk meningkatakan kedisiplinan dan membantu siswa dalam mencapai kemampuan berpikir kritis dengan baik. Salah satu model yang dianggap tepat oleh peneliti adalah model pembelajaran Problem Based Learning (PBL). Melalui langkah-langkah yang terdapat pada model pembelajaran PBL siswa dirasa dapat meningkatkan kedisiplinan dalam diri dan kemampuan berpikir kritisnya. Oleh karena itu peneliti merumuskan tujuan antara lain 1) mendeskripsikan upaya peningkatan kedisiplinan dan kemampuan berpikir kritis siswa kelas VD di SD 1 Bantul tahun ajaran 2020/ 2021 dengan menggunakan model pembelajaran Problem Based Learniang (PBL), 2) meningkatkan kedisiplinan siswa kelas VD di SD 1 Bantul dengan model pembelajaran Problem Based Learniang (PBL), 3) meningkatkan kemampuan berpikir kritis siswa kelas VD di SD 1 Bantul dengan model pembelajaran Problem Based Learniang (PBL).

Disiplin menurut Charles dapat diartikan sebagai langkah yang diambil sekolah untuk memastikan sikap dan tingkah laku siswa dapat diterima atau tidak selama di sekolah (Widi, E. N. N., Saraswati, P. \& Dayakisni, 2017). Disiplin mengarah pada sesuatu yang guru lakukan untuk memelihara sikap yang baik pada siswa di kelas. Disiplin merupakan suatu kepatuhan seseorang untuk menghormati dan melaksanakan suatu sistem yang mengharuskan orang untuk tunduk pada suatu putusan, perintah dan peraturan yang berlagu bagi dirinya (Lemhanas, 1997: 12). Elemen kedisiplinan menurut Charles dibagi menjadi 3 yaitu ketepatan waktu dalam mengerjakan tugas, perilaku yang tanggung jawab, dan relasi dengan sesama baik (Widi, E. N. N., 
921 Peningkatan Sikap Kedisiplinan dan Kemampuan Berpikir Kritis Siswa dengan Penerapan Model Pembelajaran Problem Based Learning - Halimah Dwi Cahyani, Agnes Herlina Dwi Hadiyanti, Albertus Saptoro

DOI: https://doi.org/10.31004/edukatif.v3i3.472

Saraswati, P. \& Dayakisni, 2017). Berikutnya, manfaat disiplin menurut Rachman dalam Fiana (2013: 27) yaitu 1) memberikan dukungan bagi terciptanya perilaku yang tidak menyimpang, 2) membantu siswa dalam memahami dan menyesuaikan diri dengan tuntutan lingkungan, 3) menjauhkan siswa melakukan hal yang dilarang sekolah, 4) mendorong siswa dalam melakukan kegiatan yang benar, 5) siswa belajar untuk hidup dengan kebiasaan-kebiasaan yang positif dan bermanfaat.

Kemampuan berpikir kritis adalah kegiatan dalam membuat penilaian untuk menghasilkan interpretasi, analisis, evaluasi, dan kesimpulan berdasarkan bukti, konsep, metode, kriteria, atau konteks tertentu yang digunakan sebagai penilaian yang dituju (Facione, 2011). Berpikir kritis memungkinkan siswa menemukan kebenaran dan memilah informasi yang tepat untuk digunakan dalam kehidupan sehari-hari. Berpikir kritis itu sangat penting bagi siswa, seorang siswa bisa memahami kondisi suatu daerah dengan kendala yang ada, kendala ini bisa diselesaikan jika dalam proses berpikir kritis siswa mempunyai kesadaran dalam membuat, memandu, sera mengukur apa yang akan dipelajari. siswa yang mempunyai keahlian dalam berpikir kritis bisa mempertimbangkan sesuatu dengan biak sebelum mengambil keputusan untuk mengatasi suatu permasalahan yang ada di lingkungannya (Istiqomah \& Indarini, 2021). Tujuan berpikir kritis adalah untuk menguji suatu pendapat atau ide, termasuk dalam proses ini adalah melakukan pertimbangan atau pemikiran yang didasarkan pada pendapat yang diajukan (Sapriya, 2011: 87). Tujuan berpikir kritis untuk menilai suatu pemikiran, menafsir nilai bahkan mengevaluasi pelaksanaan atau praktik suatu pemikiran dan nilai tersebut.

Berikut adalah penjelasan skema dari keenam kecakapan berpikir kritis utama: 1) Interpretasi, menginterpretasi adalah memahami dan mengekpresikan makna dari berbagai macam pengalaman, situasi, data, penilaian prosedur atau kriteria. Interpretasi mencakup sub kecakapan mengkategorikan, menyampaikan signifikasi dan mengklarifikasi makna, 2) Analisis, menganalisis adalah mengidentifikasi hubungan inferensial dan aktual diantara pertanyaan-pertanyaan, konsep-konsep, deskripsi untuk mengekpresikan kepercayaan, penilaian dan pengalaman, alasan, informasi dan opini. Analisis meliputi pengujian data, pendeteksian argumen, menganalisis argumen sebagai sub kecapakan dari analisis, 3) Evaluasi, berarti menaksir kredibilitas pernyataan-pernyataan atau representasi yang merupakan laporan atau deskripsi dari persepsi, pengalaman dan menaksir kekuatan logis dari hubungan inferensial, deskripsi atau bentuk representasi lainnya. Contoh evaluasi adalah membandingkan kekuatan dan kelemahan dari interpretasi alternatif, 4) Kesimpulan, berarti mengidentifikasi dan memperoleh unsur yang diperlukan untuk membuat kesimpulan-kesimpulan yang akal, membuat dugaan dan hipotesis, mempertimbangkan informasi yang relevan dan menyimpulkan konsekuensi dari data, 5) Eksplanasi atau Penjelasan, berarti mampu menyatakan hasil-hasil dari penalaran seseorang, menjustifikasi penalaran tersebut dari sisi konseptual, metodologis dan konstektual, 6) Regulasi Diri, berarti secara sadar diri memantau kegiatan-kegiatan kognitif seseorang, unsurunsur yang digunakan dalam hasil yang diperoleh, terutama dengan menerapkan kecakapan di dalam analisis dan evaluasi untuk penilaiannya sendiri. Dalam penelitian ini akan difokuskan pada kemampuan menganalisis dan mengevaluasi, kemampuan tersebut diperlukan dalam proses pembelajaran di sekolah dasar. Kedua kemampuan tersebut akan digunakan dalam proses pembelajaran menggunakan model pembelajaran Problem Based Learning (PBL).

Sikap kedisiplianan dan kemampuan berpikiri kritis dirasa sangat penting di abad 21 ini. Pembelajaran di abad 21 menuntut siswa untuk memiliki kemampuan berpikir kritis dengan baik dalam menentukan suatu keputusan. Berpikir kritis pada siswa bertujuan untuk dapat belajar mengatasi suatu permasalahan secara terstruktur dan kreatif. Tertanamnya suatu kemampuan berpikir kritis maka akan berkesinambungan dengan sikap disiplin yang mengarahkan untuk mengerjakan sesuatu tepat pada rencana yang ditentukan. Oleh karena itu, sikap disiplin dan kemampuan berpikir kritis adalah dua yang yang penting dalam proses pembelajaran.

Problem Based Learning (PBL) atau dalam Bahasa Indonesia disebut sebagai pembelajaran berbasis masalah adalah pembelajaran yang menggunakan masalah nyata (autentik) yang tidak terstruktur (ill- 
922 Peningkatan Sikap Kedisiplinan dan Kemampuan Berpikir Kritis Siswa dengan Penerapan Model Pembelajaran Problem Based Learning - Halimah Dwi Cahyani , Agnes Herlina Dwi Hadiyanti, Albertus Saptoro

DOI: https://doi.org/10.31004/edukatif.v3i3.472

structured) dan bersifat terbuka sebagai konteks bagi anak untuk mengembangkan keterampilan menyesuaikan masalah dan berpikir kritis serta sekaligus membangun pengetahuan baru (Rusman, 2012: 232). PBL adalah suatu model pembelajaran yang melibatkan anak untuk memecahkan suatu masalah melalui tahap-tahap metode ilmiah sehingga dapat dipelajari pengetahuan yang berhubungan dengan masalah tersebut sekaligus memiliki keterampilan untuk memecahkan masalah. Langkah-langkah PBL terdiri dari lima tahapan. Tahap 1 mengorganisasikan siswa terhadap masalah. Pada tahap ini guru menjelaskan tujuan pembelajaran dan sarana untuk logistik yang dibutuhkan. Guru memotivasi siswa untuk terlibat dalam aktivitas pemecahan masalah nyata yang dipilih atau ditentukan. Tahap 2 mengorganisasikan siswa untuk belajar. Pada tahap ini guru membantu siswa mendefinisikan dan mengorganisasikan tugas belajar yang berhubungan dengan masalah yang sudah diorientasikan pada tahap sebelumnya. Tahap 3 membimbing penyelidikan individu maupun kelompok. Pada tahap ini guru mendorong siswa untuk mengumpulkan informasi yang sesuai dan melaksanakan eksperimen untuk mendapatkan kejelasan yang diperlukan untuk menyelesaikan masalah. Tahap 4 mengembangkan dan menyajikan hasil karya. Pada tahap ini guru membantu siswa untuk berbagi tugas dan merencanakan atau menyimpan karya yang sesuai sebagai hasil pemecahan masalah dalam bentuk laporan, video, atau model. Tahap 5 menganalisis dan mengevaluasi proses pemecahan masalah. Pada tahap ini guru membantu siswa untuk melakukan refleksi atau evaluasi terhadap proses pemecahan masalah yang dilakukan (Fathurrohman, 2015: 116). Sederhananya Problem Based Learning dibagi dalam 5 langkah menurut Sani (Hagi et al., 2021) yaitu pemberian permasalahan, pengorganisasian siswa, menganalistis dan diskusi, mengembangkan dan menampilkan karya, mengkaji dan memberikan penilaian proses penyelidikan.

Penelitian serupa juga pernah dilaksanakan Wulandari (2015) membahas mengenai peningkatan keterampilan berpikir kritis dengan metode tanya jawab. Objek penelitiannya adalah siswa kelas VIII SMP dengan materi IPS. Penelitian ini berhasil meningkatkan kemampuan berpikir krittis siswa. Sigit Widodo (1981) melaksanakan penelitian untuk mengembangkan keteraampilan berpikir kritis siswa dengan model pembelajaran Problem Based Learning. (Mareti et al., 2021a) membahas penelitian mengenai peningkatan kemampuan berpikir kritis siswa dan hasil belajar dengan model Problem Based Learning. Penelitian ini dilaksanakan kepada siswa sekolah dasar kelas V. Model pembelajaran tersebut dapat meningkatkan kemampuan berpikir kritis siswa dan hasil belajar. Pada penelitian yang dilaksanakan peneliti membahas mengenai kedisiplinan dan kemampuan berpikir kritis dengan model Problem Based Learning. Perbedaan dengan penelitian sebelumnya, pada penelitian ini peneliti mengamati sikap kedisiplinan dan kemampuan berpikir kritis khususnya menganalisis dan mengevaluasi. Dipilihnya sikap dan kemampuan tersebut karena dirasa penting sebagai modal awal siswa untuk melakukan kemampuan lainnya.

Menurut pengamatan yang dilakukan rekan penulis maupun penulis bahwa penelitian yang akan dilakukan cukup menarik, mengabungkan dua hal yang saling mempengaruhi dalam pembelajaran. Sikap kedisiplinan adalah sikap penting bagi perkembangan anak dalam menyelesaikan pembelajaran dalam hal ketepatan waktu, mentaati peraturan, dan relasi. Ketiga komponen akan beriringan dengan peningkatan kemampuan berpikir kritis. Kemampuan yang perlu dimiliki siswa sejak sekolah dasar di abad 21 ini akan meningkatkan kualitas pendidikan. Belakangan ini, sikap kedisiplinan sering dikesampingkan karena dianggap tidak penting, lebbih penting hasil yang di dapat. Begitu juga pada kemampuan berpikir kritis seing di anggap terlalu sulit sehingga terus menunda untuk dikembangkan. Padahal keduanya adalah hal penting yang dapat meningkatkan keterampilan belajar siswa.

Oleh karena itu, sesuai dengan teori yang ada peneliti mengharapkan hasil penelitian model pembelajaran PBL dapat meningkatakan kedisiplinan dan kemampuan berpikir kritis siswa kelas VD SD 1 Bantul pada materi volume kubus dan balok. Selain itu, penelitian ini diharapkan bermanfaat bagi peneliti, 
923 Peningkatan Sikap Kedisiplinan dan Kemampuan Berpikir Kritis Siswa dengan Penerapan Model Pembelajaran Problem Based Learning - Halimah Dwi Cahyani , Agnes Herlina Dwi Hadiyanti, Albertus Saptoro

DOI: https://doi.org/10.31004/edukatif.v3i3.472

siswa, guru, dan sekolah dalam mengembangkan wawasan mengenai model pembelajaran PBL pada peningkatan kedisiplinan dan kemampuan berpikir kritis siswa.

\section{METODE}

Jenis penelitian ini adakah Penelitian Tindakan Kelas (PTK). PTK adalah suatu kegiatan ilmiah yang dilakukan oleh guru di kelasnya sendiri dengan merancang, melaksanakan, mengamati, dan merefleksikan tindakan melalui beberapa siklus secara kolaboratif dan partisipatif yang bertujuan untuk memperbaiki ataupun meningkatkan mutu pembelajaran di kelasnya (Kusnandar, 2008: 46). Terdapat tiga prinsip yang diperlu diperhatikan dalam pelaksanaan PTK. Penelitian ini menggunakan model dari Kemmis \& Mc. Targgart. Penelitian menurutnya merupakan pengembangan dari konsep yang diperkenalkan oleh Kuvt Lewin (Kusumah \& Dwitagama, 2010: 20). Setiap model PTK memiliki langkah pelaksanaan yang berbeda, penelitian ini menggunakan langkah-langkah PTK menurut Kemmis \& Mc. Targgart meliputi 1) perencanaan, 2) tindakan, 3) observasi, 4) refleksi (Sanjaya, 2011: 50).

Penelitian dilaksanakan dalam dua siklus sesuai dengan langkah-langkah PTK menurut Kemmis \& Mc. Targgart. Penelitian ini diujikan pada siswa kelas VD SD 1 Bantul yang berjumlah 25 anak dengan waktu pelaksanaan pada semester II tahun pelajaran 2020/2021. Penelitian difokuskan pada materi matematika tentang volume bangun kubus dan balok. Teknik pengumpulan data yang digunakan dalam penelitian ini yaitu wawancara, observasi dan tes. Wawancara dilakukan kepada guru kelas untuk mengambil data kondisi awal siswa mengenai kedisiplinan dan kemampuan berpikir kritits. Observasi digunakan untuk mengambil data kedisiplinan di setiap siklus. Tes dilakukan untuk mengambil data kemampuan berpikir kritis di setiap akhir siklus.

\section{HASIL DAN PEMBAHASAN}

Kegiatan pra siklus digunakan untuk mengetahui keadaan awal objek penelitian dalam hal ini siswa kelas VD SD 1 Bantul. Kegiatan pra siklus dilakukan dengan melakukan wawancara kepada guru kelas, melakukan obsrvasi saat pembelajaran daring dan memberikan soal tes untuk mengetahui kemampuan siswa. Pada kegiatan ini, peneliti menemukan bahwa kedisiplinan dan kemampuan berpikir kritis siswa khususnya menganalisis dan mengevaluasi masih tergolong rendah. Selanjutnya peneliti mempersiapkan perangkat pembelajaran berupa RPP, LKPD, bahan ajar, media ajar, dan soal evaluasi untuk kegiatan di siklus I dan siklus II.

Siklus I dilakukan dengan melakukan 4 langkah sesuai dengan model penelitian yang sudah dilaksanakan. Pada siklus ini peneliti melakukan dua kali pembelajaran, dan di akhir pembelajran dua dilaksanakan evaluasai kemampuan berpikir kritis siswa. Pembelajaran dilaksanakan secara daring melalui zoom dengan menerapkan model pembelajaran PBL. Peneliti berperan sebagai pengajar pada setiap pembelajaran dan seorang rekan peneliti sebagai pengamat kedisiplinan serta jalannya pembelajaran. Sikap yang nampak pada siswa belum maksimal adalah pada ketepatan pengumpulan tugas, sebanyak 7 anak dari 25 yang mengumpulkan tugas tepat waktu. Sebanyak 6 siswa dari 25 belum mendengarkan dengan baik ketika teman atau guru sedang berbicara. Mereka asik dengan kegiatan masing-masing atau saling berguru dengan teman. Selanjutnya mengenai hasil kemapuan berpikir kritis belum terlihat menonjol pada siklus ini. Kemampuan berpikir kritis untuk menganalisis lebih baik dari mengevaluasi. Kendala yang dialami pada kegaitan pembelajaran di siklus I yaitu mengenai ketepatan waktu dalam kegiatan pembelajaran, hal itu terjadi karena keterbatasan dalam pelaksanaan pembelajaran daring.

Siklus II dilakukan dengan melakukan langkah sesuai dengan model penelitian yang sudah direncanakan. Pada siklus ini peneliti melaksanakan dua kali pembelajaran dan pada akhir pembelajaran ke dua dilaksanakan evaluasi kemampuan berpikir kritis siswa. Pembelajaran dilaksanakan secara daring melalui zoom dengan 
924 Peningkatan Sikap Kedisiplinan dan Kemampuan Berpikir Kritis Siswa dengan Penerapan Model Pembelajaran Problem Based Learning - Halimah Dwi Cahyani, Agnes Herlina Dwi Hadiyanti, Albertus Saptoro

DOI: https://doi.org/10.31004/edukatif.v3i3.472

menerapkan model pembelajaran PBL. Peneliti berperan sebagai pengajar pada setiap pembelajaran dan seorang rekan peneliti sebagai pengamat kedisiplinan serta jalannya pembelajaran. Sikap kedisiplinan sudah lebih nampak pada siklus ini, hanya ada satu siswa yang terlambat mengumpulkan tugas karena bepergian, dan 5 siswa tidak memperhatikan ketika pembelajaran berlangsung. Mereka asik dengan kegiatan lain. Sisanya sudah menjalankan sikap disiplin dengan baik pada siklus II ini. Kemampuan berpikir kritis siswa juga nampak meningkat pada siklus ini walaupun tidak begitu tinggi hanya mencapai 70,25. Kemampuan berpikir kritis menganalisis masih lebih baik dari kemampuan mengevaluasi. Pada siklus II ini peneliti memperbaiki kekurangan yang ada di siklus sebelumnya.

Hasil observasi kedisiplinan siswa kelas VD SD 1 Bantul pada siklus I dan siklus II setelah direkap dengan keadaan awal maka didapatkan hasil bahwa ada peningkatan di setiap siklusnya. Sebanyak 25 siswa mengalami peningkatan pada kegiatan pembelajaran dengan model PBL ini. Hasil rata-rata peningkatan kedisiplinan siswa dapat dilihat pada gambar berikut.

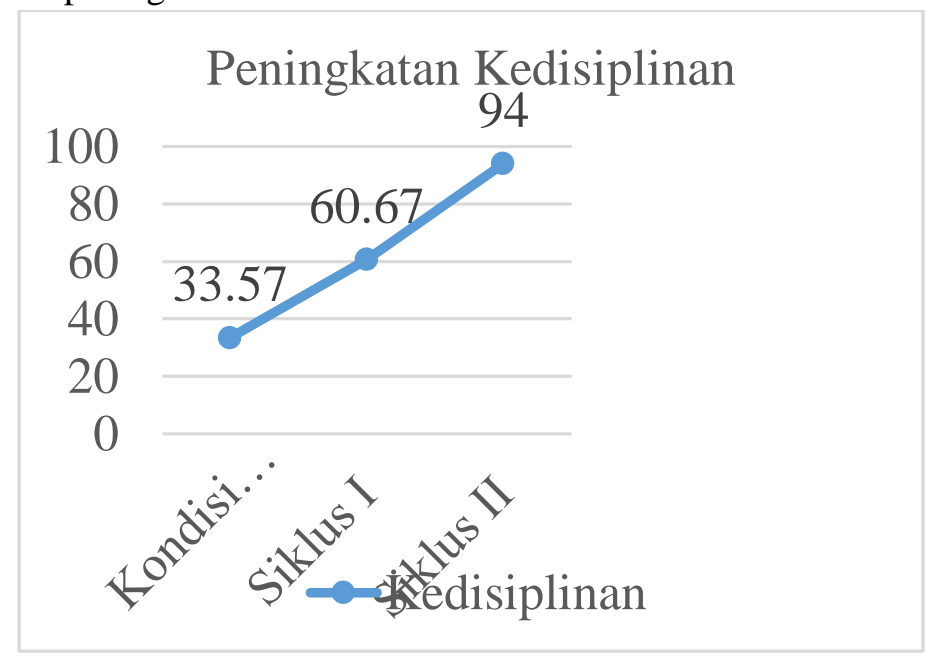

Gambar 1. Peningkatan Kedisiplinan Siswa

Berdasarkan gambar di atas, terlihat bahwa adanya peningkatan kedisiplinan siswa mulai dari kondisi awal 34,67, pada siklus I 60,67 dan di siklus II mencapai 94. Hal tersebut berdasarkan analisis yang telah dilakukan oleh peneliti, hal itu didukung dengan adanya kegiatan mengorganisasikan siswa untuk belajar dalam model pembelajaran PBL. Siswa dapa lebih menuntut siswa untuk mengerjakan melaksanakan target sesuai dengan yang diinginkan agar tidak tertinggal oleh teman yang lain. Kegiatan ini menuntut siswa untuk aktif dapat menyelesaikan tugas tepat waktu, melakukan komunikasi atau diskusi yang baik degan teman dan guru.

Kemampuan berpikir kritis siswa kelas VD SD 1 Bantul pada penelitian ini juga mengalami peningkatan pada setiap siklus dibandingkan dengan kegiatan awal. Pengukuran kemampuan berpikir kritis siswa dengan menggunakan soal evaluasi diakhir pembelajaran setiap siklus. Setiap siklus terdiri dari 4 butir soal uraian. Hasil peningkatan kemampuan berpikir kritis siswa kelas VD SD 1 Bantul dapat dilihat pada table berikut. 
925 Peningkatan Sikap Kedisiplinan dan Kemampuan Berpikir Kritis Siswa dengan Penerapan Model Pembelajaran Problem Based Learning - Halimah Dwi Cahyani, Agnes Herlina Dwi Hadiyanti, Albertus Saptoro

DOI: https://doi.org/10.31004/edukatif.v3i3.472

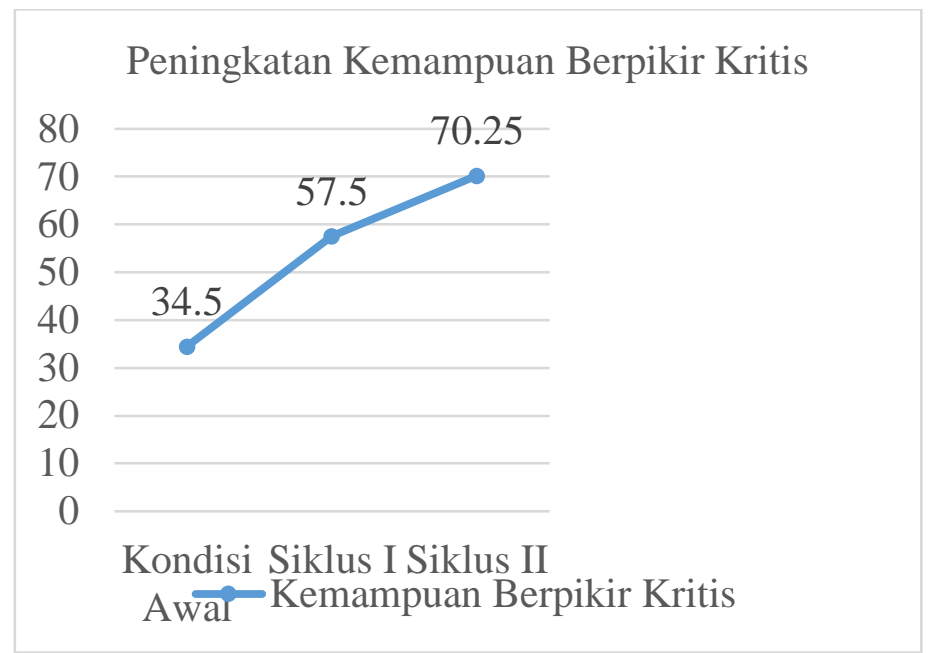

Gambar 2. Peningkatan Kemampuan Berpikir Kritis Siswa

Beradasarkan gambar di atas, dapat dilihat bahwa adanya peningkatan berpikir kritis siswa mulai dari kondisi awal 34,5, pada siklus I 57,5, dan pada siklus II 70,25. Peningkatan ini dirasa sudah memenuhi indeks keberhasilan yang direncanakan oleh peneliti yaitu peningkatan sebesar 50\% dari kondisi awal. Penerapan model pembelajaran PBL juga dapat meningkatkan kemampuan berpikir kritis siswa kelas VD SD 1 Bantul khususnya pada kemampuan menganalisis dan mengevaluasi. Kemampuan berpikir kritis siswa meningkat melalui kegiatan membimbing penyelidikan individu maupun kelompok. Pada kegiatan ini, siswa sangat berperan untuk memikirkan penyelesaian dari suatu masalah dengan hal yang paling tepat. Sesuai dengan pendapat dari Suprijono tentang model pembelajaran PBL, peneliti mengajak siswa untuk mendapatkan informasi yang tepat, melaksanakan percobaan, dan mencari penjelasan serta solusi yang mendorong siswa dapat berpikir tingkat tinggi. Peningkatan ini terjadi karena model pembelajaran PBL menuntut siswa untuk ada dalam suatu situasi bermasalah dan memecahkan permasalahan itu. Semakin siswa menemukan penyelesaian suatu masalah, maka semakin banyak pemikiran yang didapatnya.

Keterbatasan penelitian ini ada beberapa hal, baik secara teknis ataupun hasil. Secara teknis pembelajaran daring di masa pandemi mempunyai banyak keterbatasan seperti masih ada yang kesulitan mengakses internet, keterbatasan kuota yang dimiliki, kurang paham tentang teknologi, dan handphone yang dipakai bersama dalam keluarga. Selain itu hasil yang didapat dirasa juga kurang maksimal karena adanya keterbatasan dalam pembelajaran daring yang sudah disebutkan. Variabel penelitian khususnya pada kemampuan berpikir kritis belum bisa ditunjukkan ke enamnya, baru dua kemampuan yaitu menganalisis dan mengevaluasi yang dapat ditunjukan dalam penelitian ini.

Dari deskripsi di atas, dengan menerapakan model pembelajaran Problem Based Learning pada pembelajaran matematika siswa kelas VD semester II SD 1 Bantul sependapat dengan hasil yang diperoleh dari (Mareti et al., 2021) dengan pelaksanaan pembelajaran dengan Problem Based Learning mencapai keberhasilan dalam kemampuan berpikir kritis. Pada penelitian ini jelas terdapat peningkatan dari siklus I rerata 57,5 dan siklus II bertambah rerata menjadi 70,25. Kemampuan berpikir kritis juga dipengaruhi oleh kedisiplinan siswa dalam mengikuti kegiatan pembelajaran. Namun, pada penelitian terdahulu belum dibahasnya kedisiplinan bersama dengan kemampuan berpikir kritis, karena selain meningkatnya kemapuan berpikir kritis, pada penelitian ini juga terjadi peningkatan pada kedisiplinan siswa dari siklus I 60,67 meningkat pada siklus II menjadi 94. Peningkatan antar kedua variabel cukup baik pada penelitian ini setiap siklusnya. Berdasarkan hasil penelitian yang telah diuraikan di atas bahwa tujuan penelitian ini telah tercapai yang ditunjukkan oleh hasil penelitian yaitu sikap kedisiplinan dan kemampuan berpikir kritis siswa kelas mengalami peningkatan dengan penerapan model Problem Based Learning. 
926 Peningkatan Sikap Kedisiplinan dan Kemampuan Berpikir Kritis Siswa dengan Penerapan Model Pembelajaran Problem Based Learning - Halimah Dwi Cahyani, Agnes Herlina Dwi Hadiyanti, Albertus Saptoro

DOI: https://doi.org/10.31004/edukatif.v3i3.472

\section{KESIMPULAN}

Berdasarkan hasil penelitian tindakan kelas dapat ditarik benang merah bahwa: (1) penggunaan model pembelajaran Problem Based Learning dapat meningkatkan kedisiplinan siswa kelas VD SD 1 Bantul dari keadaan awal 34,67 menjadi 94, (2) penggunaan model pembelajaran Problem Based Learning dapat meningkatkan kemampuan berpikir kritis siswa kelas VD SD 1 Bantul dari keadaan awal 34,5 menjadi 70,25. Melalui kedua pandangan dapat ditarik kesimpulan bahwa penggunaan model pembelajaran Problem Based Learning dapat meningkatkan sikap kedisiplinan dan kemampuan berpikir kritis siswa kelas VD SD 1 Bantul pada muatan pelajaran matematika.

\section{DAFTAR PUSTAKA}

Desmita. (2009). Psikologi Perkembangan. Bandung: Remaja Rosdakarya.

Facione, P. a. (2011). Critical Thinking: What It Is and Why It Counts. Insight assessment, (ISBN 13: 978-1891557-07-1.), 1-28. Diambil dari https://www.insightassessment.com/CT-Resources/Teaching-Forand-About-Critical-Thinking/Critical-Thinking-What-It-Is-and-Why-It-Counts/Critical-Thinking-WhatIt-Is-and-Why-It-Counts-PDF

Fathurrohman, M. (2015). Model-Model Pembelajaran Inovatif. Jakarta: Ar-Ruzz Media.

Hagi, N. A., Kristen, U., \& Wacana, S. (2021). Model Problem Based Learning untuk Meningkatkan Keterampilan Berpikir Kreatif Siswa Sekolah Dasar Abstrak. Edukatif: Jurnal Ilmu Pendidikan, 3(2), 463-471.

Istiqomah, J. Y. N., \& Indarini, E. (2021). Meta Analisis Efektivitas Model Problem Based Learning dan Problem Posing Terhadap Kemampuan Berpikir Kritis Siswa Sekolah Dasar Pada Pembelajaran Matematika. Jurnal Cendekia: Jurnal Pendidikan Matematika, 5(1), 670-681. https://doi.org/10.31004/cendekia.v5i1.553

Kusnandar. (2008). Langkah mudah penelitian tindakan kelas sebagai pengembangan profesi guru. Jakarta: Rajagrafindo Persada.

Kusumah, W., \& Dwitagama, D. (2010). Mengenal Penelitian Tindakan Kelas. Jakarta: PT Index.

Lemhanas. (1997). Disiplin Nasional. Jakarta: Balai Pustaka.

Mareti, J. W., Herlina, A., \& Hadiyanti, D. (2021a). Model Problem Based Learning Untuk Meningkatkan Kemampuan Berpikir Kritis dan Hasil Belajar IPA Siswa, 4(1), 31-41. https://doi.org/10.31949/jee.v4i1.3047

Mareti, J. W., Herlina, A., \& Hadiyanti, D. (2021b). Model Problem Based Learning Untuk Meningkatkan Kemampuan Berpikir Kritis dan Hasil Belajar IPA Siswa, 4(1), 31-41. https://doi.org/10.31949/jee.v6i1.

Rusman. (2012). Belajar dan Pembelajaran Berbasis Komputer Mengembangkan Profesionalisme Guru Abad 21. Bandung: Alfabeta.

Sanjaya, W. (2011). Penelitian tindakan kelas. Jakarta: Kencana.

Sapriya. (2011). Pendidikan IPS: Konsep dan Pembelajaran. Jakarta: PT Raja Grafindo Persada.

Sigit Widodo. (1981). Pengembangan Keterampilan Berpikir Kritis Peserta Didik Dengan Menggunakan Model Pembelajaran Berbasis Masalah (Problem Based Learning) Melalui Isu-Isu Sosial Ekonomi Pasca Penggenangan Waduk Jatigede Dalam Pembelajaran Ips Di Smpn 2 Wado Kabupaten Sumeda. Keterampilan Berpikir Kritis, Problem Based Learning, 53(9), 1689-1699. Diambil dari https://ejournal.upi.edu/index.php/pips/article/download/4712/3284

Sisdiknas. (2003). Undang-Undang Republik Indonesia No 20 Tentang Sistem Pendidikan Nasional. Jakarta: 
927 Peningkatan Sikap Kedisiplinan dan Kemampuan Berpikir Kritis Siswa dengan Penerapan Model Pembelajaran Problem Based Learning - Halimah Dwi Cahyani , Agnes Herlina Dwi Hadiyanti, Albertus Saptoro

DOI: https://doi.org/10.31004/edukatif.v3i3.472

Direktorat Pendidikan Menengah Umum, 6. Diambil dari http://stpi-binainsanmulia.ac.id/wpcontent/uploads/2013/04/Lamp_2_UU20-2003-Sisdiknas.doc

Tawil, \& Liliasari. (2014). Berpikir Kompleks dan Implementasinya dalam Pembelajaran IPA. Makasar: Badan Penerbit UNM.

Widi, E. N. N., Saraswati, P. \& Dayakisni, T. (2017). Kedisiplinan Siswa-Siswi Sma Ditinjau Dari Perilaku Shalat Wajib Lima Waktu. Jurnal Psikologi Islam, 4(2), 135-150.

Wulandari, P. N. (2015). Peningkatan Keterampilan Berpikir Kritis Melalui Penerapan Teknik ProbingPrompting dalam Pembelajaran IPS (Penelitian Tindakan Kelas di Kelas VIII-4 SMP Negeri 1 Bandung). 